\title{
A MÚSICA COMO AGENTE TRANSFORMADOR NA VIDA DO INDIVÍDUO
}

\section{ARTIGO DE REVISÃo}

ROCHA, Luiz Renato Da Silva ${ }^{1}$

ROCHA, Rafael Da Silva ${ }^{2}$

ROCHA, Luiz Vanderlei ${ }^{3}$

ROCHA, Luiz Renato Da Silva. ROCHA, Rafael Da Silva. ROCHA, Luiz Vanderlei. A música como agente transformador na vida do indivíduo. Revista Científica Multidisciplinar Núcleo do Conhecimento. Ano 03, Ed. 10, Vol. 01, pp. 05-40 Outubro de 2018. ISSN:2448-0959

\section{RESUMO}

Este trabalho se trata da música como agente transformador na vida do indivíduo, um estudo que inclui uma reflexão de como é vista a música cristã e secular e as possíveis contribuições desse contexto para compreendermos mais sobre suas diferenças. $E$ teve como objetivo geral: analisar a formação musical recebida nas igrejas evangélicas e como objetivos específicos: compreender como às igrejas evangélicas, tem gerado músicos profissionais para o mercado de trabalho, investigar as vantagens do ensino musical nas igrejas evangélicas bem como, analisar os desafios enfrentados pelos músicos evangélicos na sua atuação profissional. A metodologia

1 Pós-Graduado Em Educação Musical Pelo Centro De Estudos Avançados Em PósGraduação Em Pesquisa- Cesap.

2 Pós-Graduado Em Educação Musical Pelo Centro De Estudos Avançados Em PósGraduação Em Pesquisa- Cesap.

${ }^{3}$ Pós-Graduado Em Educação Musical Pelo Centro De Estudos Avançados Em PósGraduação Em Pesquisa- Cesap. 
aplicada foi de abordagem qualitativa e se desenvolveu em dois momentos: no primeiro momento análise documental e no segundo momento, entrevista através de um questionário com cinco músicos evangélicos. De acordo com os entrevistados e nas suas reflexões, foi permitido compreender a formação inicial até a vida de músico profissional, observamos que há uma grande abertura no mercado musical para esses músicos profissionais denominados cristãos evangélicos que naturalmente vem crescendo e contribuindo ao abastecer as bandas de forma geral como músicos profissionais e competentes.

Palavras-chave: Música Evangélica, Ensino, Mercado de Trabalho.

\section{INTRODUÇÃO}

Esta pesquisa foi elaborada com o intuito de registrar, valorizar e dar maior visibilidade ao trabalho com músicas, trazendo a luz o resgate teórico de algumas questões relacionadas ao ensino de música nas igrejas evangélicas.

A música é importante na vida do ser humano, porque possui um papel fundamental no processo de socialização. Ela nos traz sensação de vitória, recordação, saudades, alegria, tristeza, é algo que nos tocam.

Para Rosa (1990, p. 19) identifica a música como "uma linguagem expressiva e as canções são veículos de emoções e sentimentos, e podem fazer com que o indivíduo reconheça nelas seu próprio sentir".

Todos ouvem, apreciam, compartilham, mas, poucos sabem de sua real importância e em que ela pode contribuir.

Segundo Brito (2003, p.31)

É difícil encontrar alguém que não se relacione com a música [...]: escutando, cantando, dançando, tocando um instrumento, em diferentes momentos e por diversas razões. [..] surpreendemo-nos cantando aquela canção que parece ter " cola" e que não sai da nossa cabeça e 
não resistimos a, pelo menos, mexer os pés, reagimos um ritmo envolvente [...].

Não é por acaso, que a música é empregada nos diversos campos de atuação humano. Nos filmes, anúncios públicos, telejornais, desenhos animados, propagandas, programas eletrônicos entre outros.

A presença da música sempre esteve presentes na vida dos seres humanos em todas as épocas, culturas, raças, tribos e nações. Ou seja, a música é universal, ela ultrapassa as barreiras do tempo e do espaço.

Nesse sentido o objetivo geral do trabalho foi analisar até que ponto a formação musical recebida nas igrejas evangélicas pode contribuir na formação do músico profissional. Os objetivos específicos foram compreender como às igrejas evangélicas tem gerado músicos profissionais para o mercado de trabalho, investigar as vantagens do ensino musical das igrejas evangélicas, bem como, analisar os desafios enfrentados pelos músicos evangélicos na sua atuação profissional.

A metodologia adotada nesse estudo aponta para a pesquisa bibliográfica de autores especializados no assunto, levantadas por meio de livros diversos, revistas técnicas, artigos científicos e pesquisa com os cotidianos para a produção de dados que compõem a pesquisa.

A importância desse tema, a música como agente transformador na vida do indivíduo se justifica por perceber que no mercado de trabalho há presença de vários músicos que atuam em diversas áreas tais com: sopro, cordas e percussão que tiveram sua iniciação musical em igrejas evangélicas.

Para tanto, o trabalho foi distribuído em oito capítulos, para melhor explicitar o caminho percorrido para atingir os objetivos da pesquisa, e está constituído da seguinte forma:

No primeiro capítulo, encontra-se a introdução, objetivos, e metodologia da pesquisa. 
No segundo capítulo, os pressupostos teóricos que fundamentaram e serviram de alicerce para a pesquisa, iniciando com a definição de música suas funções e os três elementos básicos que ela pode ser dividida, também no mesmo capítulo, falamos das notas musicais, do ensino de músicas oferecido pelas igrejas evangélicas.

No terceiro capítulo, contextualizando o movimento gospel no Brasil, a reforma protestante e falamos ainda, do maior vulto da reforma protestante.

No quarto capítulo, início dos coros e sua influência nas bandas do movimento protestante, o trabalho musical nas igrejas do século XX, e no final do capítulo falamos de um pouco de história dos movimentos dos cânticos.

No quinto capítulo, a criação de escolas de música nas igrejas evangélicas bem como, a educação formal, que é aquela que se refere à estruturação, organização e planejamento intencional de um modo sistemático.

No sexto capítulo, explicito o delineamento metodológico da pesquisa, onde iremos delimitar os sujeitos da pesquisa.

No sétimo capítulo, resultados e discussão dos dados obtidos através das entrevistas. Em seguida apresentaremos a produção dos dados, bem como contextualização do ambiente da pesquisa e seus sujeitos.

E no oitavo capítulo, inserimos as considerações finais, fazendo um paralelo entre a teoria e a prática vivenciada nas igrejas, e apresentamos as conclusões, as referências bibliográficas e os anexos que embasaram a pesquisa em todo o seu percurso.

\section{O QUE É MÚSICA?}

A música é a sucessão de sons e silêncio organizada ao longo do tempo. Esta tem várias funções: a função artística que é considerada por muitos como sua principal função, porém existem outras, como a militar, educacional ou terapeuta (musicoterapia) e religiosa. 
Para Berchem (apud KRZESINSKI e CAMPOS, 2006, p.115) “a música é a linguagem que se traduz em forma sonora capaz de expressar e comunicar sensações, sentimentos e pensamentos, por meio da organização e relacionamento entre o som e o silêncio.

A música pode ser divida em três elementos básicos: a melodia, o ritmo, e a harmonia. A melodia é a organização simples de uma série de sons musicais, constituindo o elemento principal da música, já o ritmo é o que age em função da duração do som e quanto tempo cada parte da melodia continuará à tona, a harmonia é a combinação dos sons simultaneamente, é o argumento agradável de sons.

Segundo Brito (2003, p. 26) a música tem sido interpretada como "[...] melodia, ritmo, harmonia, [...] elementos que estão muito presentes na produção musical dentre outras possibilidades de organização do material sonoro.

Entretanto, esses sons são chamados notas musicais, cada um deles é representado por uma letra: Dó (C), Ré (D), Mi (E), Fá (F), Sol (G), Lá (A) e Si (B).

Ainda há outros símbolos de alteração das notas: o sustenido (\#) e o bemol (b). Cada uma dessas notas possui uma altura diferente, sendo graves (freqüência menor mais "grossa", como a voz masculina) ou agudas (freqüência maior, mais "fina", como a voz feminina). A organização dessas alturas é chamada de escala musical.

A música movimenta, mobiliza, e por isso contribui para a transformação e para o desenvolvimento. E segundo Wilhems (apud, GAINZA, 1988, P. 36-37)

Cada um dos aspectos ou elementos da música corresponde a um aspecto humano específico, ao qual mobiliza intensamente: o ritmo musical que induz o movimento corporal, a melodia estimula a afetividade, a ordem ou a estrutura musical ( na harmonia ou na forma musical) contribui ativamente para a afirmação ou para a restauração da ordem mental do homem. 
A combinação diversificada dos elementos da melodia, ritmo e harmonia dão origem ao que chamamos de estilos musicais. Entre alguns exemplos, podemos citar rock, pop, rap, funk, techno, samba, country, jazz e blues.

\subsection{ENSINO DE MÚSICA OFERECIDO PELAS IGREJAS EVANGÉLICAS}

As igrejas evangélicas na sua maioria possuem uma escola de música sacra própria, que atende não somente aos seus congregados em várias faixas etárias, mas também as pessoas da comunidade da qual faz parte.

Este ensino visa contribuir para a aprendizagem do indivíduo capacitando para tocar algum instrumento musical disponibilizado pela obra social da igreja, já que as escolas de educação básicas não oferecem ensino efetivo de música, limita apenas a formação de pessoas.

Como alguns têm vocação para música, acabam procurando a escola de música das igrejas que as recebem de mãos abertas na intenção de formar futuros músicos profissionais.

Sendo assim, a o crescimento do número de congregados aumentam cada vez mais visto que, são muitos voltados para o campo da música. Para desenvolver essas atividades musicais, as igrejas disponibilizam profissionais que realizam trabalhos de voluntariados como regentes, pianistas ou simplesmente estudantes na área de música.

As igrejas têm buscado manter pessoas preparadas musicalmente para liderar as atividades musicais. Algumas passaram a dar a esse líder da área de música, responsável pela condução e execução das atividades musicais eclesiásticas, o título de "ministro de música" ou "diretor de música" ou "ministro de louvor", especialmente àqueles que, sempre vem buscando um aprimoramento e interesse na formação em educação musical e que lideram e administram os grupos musicais da igreja. 
O protestantismo constitui-se numa das três principais divisões do cristianismo, ao lado do catolicismo romano e da Igreja ortodoxa, e tem na sua formação uma história de pouco mais de quatro séculos. Surgiu no século XVI, com os reformadores Martinho Lutero na Alemanha, Úlrico Zuíngliona Suíça de língua alemã e João Calvino em Genebra. As igrejas protestantes, buscando a valorização da música em seus cultos, dão grande ênfase à educação musical, ainda que informalmente. Sua influência musical é tão grande nos músicos que buscam uma escola formal de música que nos despertou para investigar a influência desta formação e quais os desafios encontrados por músicos que estudaram a música sacra protestante diante de uma formação musical mais ampla e laica (Veras; Medeiros; Mattos, 2011).

A história do movimento evangélico revela que através do ensino musical oferecido pelas igrejas que buscam preparar os músicos de forma prática, alguns instrumentistas e cantores participam também do mercado de trabalho musical secular. Desta forma, esta pesquisa busca compreender e ampliar a formação de músicos evangélicos e assim, contribuir com outras pesquisas acadêmicas que abordam questões de ensino de música nas igrejas evangélicas.

Com o crescimento das comunidades evangélicas, espalhadas inclusive em lugares de difícil acesso, cresce a possibilidade do ensino. Possivelmente, se não fosse à ampliação dos respectivos templos, a música não chegaria a muitos lugares como tem chegado. Esse fato é tão significativo, que as próprias estruturas administrativas das comunidades respectivas tornaram-se espaço oficial de ensino musical, em alguns casos tornando-se até curso superior em música.

\section{CONTEXTUALIZANDO O MOVIMENTO GOSPEL NO BRASIL}

A palavra evangélico originou do inglês gospel procedente da língua antiga 'God-spell' que significa good tidings, ou good news, em português, "boas novas," referindo-se aos Evangelhos da Bíblia que nos narram as boas novas ao mundo o nascimento de Jesus. Então, "music gospel' é igual a musica dos evangelhos, a boa nova da salvação e traduzindo para o português ficaria linearmente: música evangélica (CICERO, 2014). 
Quem trouxe este estilo de louvor ao Brasil foram os evangélicos batistas e presbiterianos vindos dos Estados Unidos no século XIX em 1882. Introduziram este gênero Gospel a partir do próprio estilo americano simplesmente traduziam para a língua portuguesa os seus hinários e a famosa harpa cristã que ainda é bem aceita por muitos evangélicos (CICERO, 2014). A explosão da música evangélica no Brasil ocorreu principalmente nas décadas dos anos 80 e 90 e até os dias de hoje.

Este gênero musical gospel traz uma missão sublime de expressar uma fé religiosa da salvação em Cristo. O mesmo tem uma história remota principalmente do inicio da colonização dos Estados Unidos, quando houve uma grande aproximação dos antigos estilos musicais afros conectando a gospel.

As composições foram denominadas de "Negros Spirituals" que em português poderíamos chamar de canções espirituais de influência negra. Estes negros eram escravos vindos da África para colonizarem a América do Norte em situações muito difícil e principalmente adversa de todo o seu contexto cultural.

Eles foram firmes e autênticos em criarem um novo estilo musical que transcendeu aos dias contemporâneos. Há uma grande semelhança entre os negros que vieram escravos da África para o Brasil e conservou a base de sua cultura mesmo com tanta perseguição (RAMOS - 2009).

O mais conhecido pai da música gospel é Thomas A. Dorsey (1899-1993) um grande compositor deste estilo musical do século XX. A música harmoniosa e diversificada em várias vozes (coral), um solista, piano, órgão, guitarra, bateria, baixo, formando um pequeno conjunto musical.

Deste gênero derivaram-se outros como o Rock, Blues, Jazz etc, tendo como o grande representante Elvis Presley (1935-1977) e outros representantes deste estilo musical cristã. No início de sua vida ele foi um líder azul pianista conhecido como Georgia Tom. Como formulado por Dorsey, música gospel combina com louvor cristão com os ritmos do jazz e de blues. 
Sua concepção, também se desvia daquilo que tinha sido, a esse tempo, a prática hinário padrão, referindo-se explicitamente ao eu, e a relação do auto de fé e Deus, ao invés de o indivíduo subsumido no grupo através de crença.

Dorsey, que nasceu em Villa Rica, Geórgia, foi o diretor musical da Pilgrim Baptist Church, em Chicago a partir de 1932 até o final de 1970. Sua composição mais conhecida, 'Take My Hand, Precious Lord', foi realizada por Mahalia Jackson (19111972) e era um dos favoritos do reverendo Martin Luther King Jr (ROUTLEDGE, 2002).

Segundo Cícero (2014), outro compositor que influenciou fortemente foi George Bernard que nasceu na cidade de Youngstown, em Ohio, nos Estados Unidos, no dia 4 de fevereiro de 1873, filho de pai que trabalhava como mineiro. Ainda criança, George se mudou para o estado de lowa - primeiro para Albia, depois para Lucas.

Aos dez anos de idade, George se converte. Desde criança teve o desejo de se tornar um evangelista cristão - algo que foi difícil, visto que desde os dezesseis anos já era o responsável para sua mãe e suas quatro irmãs, isto porque seu pai morrera pouco tempo antes.

Foi difícil para ele, que até a própria educação teve de cuidar no final de sua vida. Foi reconhecido pelos seus mais de trezentos hinos, e morreu na de Reed City, aos 85 anos de idade, em 10 de outubro de 1958. Até hoje essa última cidade possui um museu em sua homenagem.

Cardoso (2011), ao pesquisar sobre o movimento evangélico afirma que por volta de 1912, quando George já vivia em Michigan ele voltava de série de conferências evangelísticas, em Michigan e em Nova York. Nesse momento ele começa a passar por algumas dificuldades. Isso faz com que ele comece a fazer um estudo sobre a cruz, no contexto do plano de Deus para a salvação.

Nisso, ele lê um texto de Paulo, em Filipenses 3.10, falando sobre seus sofrimentos. Após ler o texto bíblico, ele sentiu o desejo em escrever um hino sobre o tema. O hino já estava quase pronto, mas faltava finalizá-lo. 
Para tanto, foi à igreja de um amigo, o Reverendo Bostwick, para participar de uma série de cultos de avivamento. Isso foi mais que o suficiente para ele pudesse concluir o hino, que fora tão cuidadosamente elaborado. No dia 7 de junho de 1913, ele apresentou o hino em uma conferência, em Pokagon, por um grupo musical composto por cinco vozes e um violão (CARDOSO, 2011).

\subsection{A REFORMA PROTESTANTE}

A Reforma Protestante foi um movimento de caráter religioso que marcou a passagem do mundo medieval para o moderno. Entre um dos fatores de grande relevância que assinalaram esse período de transformações podemos destacar o novo contexto econômico do período. No ambiente das cidades, os comerciantes burgueses eram malvistos pela Igreja. Segundo os clérigos, a prática da usura (empréstimo de dinheiro a juro) feria o sagrado controle que Deus tinha sobre o tempo.

Além dos comerciantes, a própria crise econômica feudal também instigou a população a questionar os dogmas impostos pela Igreja. Os clérigos estavam muito mais próximos das questões materiais envolvendo o poder político e a posse de terras, do que preocupados com as mazelas sofridas pela população camponesa. Um dos mais claros reflexos dessa situação pôde ser notado com o relaxamento dos costumes que incitava padres, bispos e cardeais a não cumprirem seus votos religiosos.

Segundo Palisca (2007), já no século XII apareceram os primeiros movimentos que questionavam as crenças e práticas do catolicismo. Entre outras manifestações, podemos destacar o papel exercido pelos cátaros, originários da região sul da França. Naquela região as distinções culturais históricas propiciaram a ascendência de uma fé cristã à parte dos ditames da Igreja Católica. Realizando uma leitura própria do texto, os cátaros tinham valores morais bastante rígidos que se contrastava com o comportamento dos líderes clericais.

No século posterior, vendo a grande presença do movimento religioso, o papa Inocêncio III ordenou a realização de uma cruzada que - entre 1209 e 1229 - aniquilou o movimento cátaro. Além disso, as acusações de feitiçaria eram bastante corriqueiras 
entre indivíduos considerados suspeitos ou infiéis. Já na Idade Média, a Igreja criou o Tribunal da Santa Inquisição que percorria diversas regiões da Europa, reprimindo aqueles que ameaçassem seu poderio religioso e ideológico (GROUT; PALISCA, 2007).

\subsection{O MAIOR VULTO DA REFORMA PROTESTANTE}

Apesar da grande influência gospel no meio evangélico brasileiro em pleno século XXI, o movimento da Reforma Protestante iniciou com o Fundador do luteranismo, Martinho Lutero foi o maior vulto da reforma protestante. Seus pais, de origem camponesa, aspiravam dar ao filho uma educação aprimorada, fazendo-o advogado. Lutero estudou em várias cidades e ingressou, em 1501, na Universidade de Erfurt, onde estudou os clássicos latinos, bacharelando-se em artes, lógica, retórica, física e filosofia. Dois anos depois, concluía seu mestrado em matemática, metafísica e ética (GROUT; PALISCA, 2007).

Em 1505, quando se preparava para o estudo de direito, foi abalado por dois acontecimentos: a morte repentina de um amigo e o fato de quase ter sido atingido por um raio. Isto, segundo alguns, foi o fator decisivo para sua entrada no mosteiro dos eremitas agostinianos, em Erfurt, em 17 de julho de 1505. Lutero destacou-se na vida monástica, sendo ordenado sacerdote em 1507. Em 1508 foi para Wittemberg, onde se bacharelou em teologia um ano depois. De fins de 1510 a princípios de 1511 permaneceu em Roma para tratar de assuntos de sua ordem, e ali se sentiu chocado com o secularismo da Igreja e o baixo nível moral da cidade. Em 1512, novamente em Wittenberg, onde passaria o resto da vida, recebeu o título de doutor em teologia. Tornou-se professor sobre a Bíblia, cabendo-lhe o cargo, em 1515, de diretor de estudos e vigário distrital, encarregado de 11 mosteiros.

A partir desse momento, dedica-se ao estudo de Guilherme de Occam, a quem chama de "meu mestre", Duns Scotus e santo Agostinho, dedicando a este último grande predileção, sobretudo por Ihe ter aberto os olhos contra o domínio de Aristóteles na teologia. 
O pensamento de Lutero centralizava-se em alguns pontos que viriam a ser os princípios da reforma protestante: o sacerdócio universal dos crentes, a justificação pela fé, a autoridade exclusiva da Bíblia em questões de fé, a pessoa salvadora de Cristo. Só admitia dois sacramentos - o batismo e a eucaristia (GROUT; PALISCA, 2007).

Segundo Lutero, a soberania de Deus se exerce sobre todas as fases da existência, incluindo a ordem política, fato este que o levou ao conceito de que os dois reinos - o de Deus e o do mundo -, embora com suas esferas próprias e definidas, estão sujeitos à soberana vontade de Deus, e ambos, portanto, exigem a leal submissão dos crentes. Negava, assim, a submissão do Estado à Igreja. Sua doutrina teria oferecido, dessa forma, a ideologia oportuna ao nascente nacionalismo alemão, retardado em relação à unificação nacional já processada na Espanha, na França e no Reino Unido.

Outro pensamento de Lutero é sobre a íntima relação entre profissão e trabalho teria dado origem ou, pelo menos, favorecido o processo de secularização, fato que colocaria o reformador na base dos grandes movimentos de renovação do nosso tempo, abrindo caminho para a Idade Moderna (GROUT; PALISCA, 2007).

Por outro lado, a insistência de Lutero na idéia da pureza da doutrina, como único critério infalível para a Igreja, estabelecia um obstáculo cada vez maior para o desenvolvimento de novas concepções no terreno ético.

A profissão, tomada como missão, tornava-se absolutizante e alienante. Ele considerava "arrogância" o cristão mudar do estado e profissão em que Deus o colocara - e disso resultava a manutenção do tradicionalismo econômico.

Para o teólogo protestante Ernst Troeltsch (Protestantismo e Progresso, 1912), há necessidade de se distinguir entre um protestantismo velho e um novo. Pois a doutrina denominada velha depositava uma confiança irrestrita na Bíblia, como fonte última e definitiva da verdade e levaria ao desprezo de uma atividade intelectual criadora.

Nos séculos, XIV e XV alguns teólogos também indicavam que os valores absolutos da Igreja já não tinham a mesma força mediante as transformações históricas 
experimentadas. $O$ inglês John Wycliffe $(1330-1384)$ redigiu alguns ensaios onde denunciava as ações corruptas da Igreja e defendia a salvação espiritual por meio da fé. Em certa medida, as teorias lançadas por esse pensador viriam a influenciar as obras de Martinho Lutero, no século XVI.

Jan Huss (1370 - 1415) foi um padre que se preocupou em traduzir o texto bíblico em outras línguas, pois os cultos, as missas eram celebradas em latim e o povo não entendia o contexto bíblico e sacro e denunciou o comportamento dos clérigos católicos.

A pregação por ele empreendida, ao longo da Boêmia, motivou a violenta reação das autoridades do Sacro-Império Germânico que ordenaram sua morte pela fogueira. A morte de Huss deu origem a um movimento popular conhecido como hussismo. A grande maioria de seus integrantes era camponeses, pobres insatisfeitos com sua condição de vida social, econômica e humana.

O movimento renascentista também deu passos importantes no questionamento do papel exercido pela Igreja Católica. A teoria empirista de Francis Bacon; o heliocentrismo defendido por Nicolau Copérnico; e a física newtoniana descentralizou o monopólio intelectual da Igreja. O conhecimento gerado por esses e outros indivíduos lançava a ideia de que o homem não necessitava da chancela de uma instituição, principalmente religiosa, que o concedesse o direito de conhecer a Deus ou o mundo (CHAMPLIN; BENTES, 1994).

\section{O INICIO DOS COROS E SUA INFLUÊNCIA NAS BANDAS DO MOVIMENTO PROTESTANTE}

A origem do coral cristão remonta do século IV. Pouco depois do Édito de Milão (313 d.C.) quando a perseguição aos cristãos foi interrompida. Sob Constantino, os corais foram desenvolvidos e treinados para ajudar na celebração da Eucaristia. A prática foi adotada do costume romano de dar início às cerimônias imperiais com música solene. Foram fundadas escolas especiais e os cantores do coral foram reconhecidos como 
clero de "segunda corda [classe]". As raízes do coral se encontram nos dramas e templos pagãos gregos.

Para Durant (1950, p. 1027)

Na Idade Média como na antiga Grécia, a principal fonte dramática estava na liturgia religiosa. A própria Missa foi um espetáculo dramático; o santuário era um cenário sagrado; os celebrantes vestiam roupas simbólicas; o sacerdote e os acólitos promoviam diálogos; as respostas antifonais do sacerdote e do coral, e do coral ao coral, sugeriam precisamente essa mesma evolução dramática do diálogo que havia gerado a obra sagrada de Dionísio.

Com o advento do coro na igreja cristã, a música escapou das mãos do povo para as mãos do pessoal clerical composto por cantores treinados. Esta mudança deveu-se em parte ao fato de que as doutrinas heréticas se espalhavam pelo cântico dos hinos. O clero sentiu que se o ato de cantar hinos estivesse sob seu controle, isso restringiria a expansão de heresia. Mas isso também estava arraigado no crescente poder do clero como principal ator no drama cristão.

Desta forma, em 367 d.C., a música da congregação foi completamente eliminada. Sendo substituída por corais treinados. Assim, pois, nasceu o cantor profissional na igreja. $\mathrm{O}$ ato de cantar na adoração cristã agora estava sob o controle do clero e do coral.

Ambrósio (339-397 d.c.), criou os primeiros hinos pós-apostólicos. Tais hinos foram modelados segundo os modos gregos e chamados por nomes gregos. Ambrósio também criou uma coleção de cânticos litúrgicos, os quais ainda são utilizados em algumas igrejas católicas. O cântico litúrgico é o descendente direto do cântico pagão romano, o qual remonta às antigas cidades da Sumaria.

Os coros papais começaram no século V. Quando Gregório o Grande tornou-se Papa, perto do fim do século VI, ele reorganizou a ScholaCantorum (escola de cantores) em Roma. (Esta escola foi fundada pelo Papa Sylvester que morreu em 335 d.C.). Com 
esta escola, Gregório estabeleceu cantores profissionais que treinariam coros cristãos ao longo do Império Romano. Estes cantores eram treinados por nove anos. Eles tinham que memorizar cada cântico - inclusive os famosos "cânticos gregorianos". Gregório eliminou os últimos vestígios da música pela congregação, acreditando que cantar era direito exclusivo dos cantores treinados (DURANT, 1913).

Ele acreditava que a música era uma função clerical. Corais e cantores treinados juntamente com o impedimento do canto pela congregação refletiam a postura cultural dos gregos. Similar ao oratório (diálogo profissional), a cultura grega era baseada na dinâmica artista/auditório. Esta característica estava presente nos templos de Diana e dos dramas gregos e foi transportada diretamente para as igrejas dos primeiros séculos que ainda tinham uma influência grega na sua liturgia.

Os corais infantis remontam aos dias de Constantino. A maioria deles foi criada nos orfanatos. Os corais infantis permaneceram na igreja por centenas de anos após sua fundação. O coral dos Meninos Cantores de Viena, por exemplo, foi fundado em Viena, Áustria em 1498. O coro cantava exclusivamente para a corte, na Missa, em concertos privados e eventos do Estado. Um fato pouco conhecido é que os corais de meninos são de origem pagã. Os pagãos acreditavam que as vozes dos meninos possuíam poderes especiais.

Em muitas igrejas contemporâneas, sejam carismáticas ou não, o coro foi substituído pelo fenômeno recente do grupo de louvor que é um grupo musical da igreja responsável pelos cânticos e adoração no templo. O edifício tem poucos símbolos religiosos da igreja católica Romana ou Ortodoxa. Na frente igreja há uma plataforma, um púlpito, algumas plantas e vários amplificadores de som e microfones, além de instrumentos musicais tais como guitarra, contrabaixo, piano, teclado, bateria e outros instrumentos de percussão. Usualmente, a roupa dos congregados que dirigem a música é marcada por uma roupa mais atual, diferente dos músicos que participavam dos coros da igreja renascentista. Há cadeiras fixas ou cadeiras de teatro substituindo os bancos. A letra das músicas cantadas e tocadas, geralmente, é projetada na parede ou na tela por um retroprojetor ou projetor de vídeo e sua poesia varia desde letras mais tradicionais até outras contemporâneas. 
Começando por Dublane, em 1962 na Escócia, um grupo de músicos ingleses insatisfeitos tratou de revitalizar os cânticos cristãos tradicionais. Influenciados por músicos populares, eles produziram um novo tipo de música. Esta reforma preparou o cenário para que mudanças musicais revolucionárias se arraigassem na igreja cristã protestante.

Assim, a guitarra substituiu o órgão como instrumento principal dirigindo a adoração na igreja protestante. O modelo de músicos que dirigia os "novos cânticos", influenciados pelo rock e pela cultura popular, tomaram o lugar dos coros presentes desde a idade média nas igrejas cristãs (DURANT, 1913).

\subsection{O TRABALHO MUSICAL NAS IGREJAS DO SÉCULO XX}

O século XX foi um momento de diversas transformações em todas as áreas, de modo que os fatores tecnológicos e sociais, por exemplo, foram de extrema importância na evolução da cultura musical (GROUT; PALISCA, 1994). A grande verdade é que o início do século passado foi um momento de diversas experiências musicais, o que influenciou por demais os rumos que a música do período iria tomar.

Foi no século $X X$ que tendências como o Impressionismo, o Expressionismo, a Politonalidade, a Atonalidade, o Serialismo, dentre outras, passaram a se colocar como forças opositoras às tendências românticas do século anterior (BENNET, 2007). As influências jazzísticas também tiveram seu papel, uma vez que o jazz estava se iniciando juntamente com o século e os seus progenitores (o blues e o ragtime) já se faziam conhecidos nos grupos negros norte-americanos. O século XX viveu um grande "boom" de informações e isso resultou nas grandes mudanças ocorridas.

Foi também no século $X X$ que as primeiras gravações começaram a acontecer. $O$ gramofone, antecessor da vitrola e inventado no final do século XIX, passou a ser utilizado, de modo que aqueles que não podiam mais, se fazer presentes nos grandes concertos, podiam ouvir uma orquestra inteira em suas próprias casas. 
O jeito de tocar alguns instrumentos mudou (como no caso do baixo acústico, usado no jazz), novos instrumentos foram surgindo (como a bateria) e o chamado estilo popular cresceu em divulgação, uma vez que a mídia passou a atuar em sua difusão. O rádio, por exemplo, lançou diversos cantores e cantoras, os quais obtiveram grande sucesso. Isso tudo representou uma tremenda mudança na história da música como um todo, o que inclui, é claro a música eclesiástica.

Ainda na primeira metade do século XX, o piano era largamente usado nas igrejas, assim como os corais e grupos vocais, de modo que aqueles hinários (Cantor Cristão e Harpa), traduzidos para o português eram parte integrante dos cultos. O cantor cristão, publicado pela primeira vez em 1891 e sucedido por diversas outras novas edições, foi o primeiro hinário oficial das igrejas batistas no Brasil.

A Harpa Cristã, por sua vez, foi lançada em 1922, sendo o hinário oficial da Igreja Assembléia de Deus. O hinário Salmos e Hinos, oriunda da Igreja Evangélica Fluminense, havia sido lançado em 1861 e serviu de influência para ambos.

Os músicos que mais possuem letras ou traduções do cantor cristão, por exemplo, são: Salomão Luiz Gisburg, William Edwin Entzminger, Henry Maxwell Right, Manoel Avelino de Souza e Ricardo Pitrowsky. Estes homens serviram à sua geração de tal maneira que, ainda hoje, muitos desses hinos são ainda cantados e tocados ao redor do mundo, principalmente em igrejas mais tradicionais na sua forma de culto (FREITAS; Marcus, 2013).

\subsection{UM POUCO DE HISTÓRIA DOS MOVIMENTOS DOS CÂNTICOS}

Charles A. Tindley foi o pioneiro do gênero gospel. Ele produziu várias composições nos anos 10, mas somente nos anos 20 e 30 elas alcançaram popularidade.

Outro importante compositor gospel nos anos 30 foi Hebert W. Brewster (pastor batista). A maior parte de suas canções era composta exclusivamente para o coral "Cantores de Brewster". 
Para tanto, as músicas foram interpretadas como "secularização" do gênero de música religiosa, a profissionalização e a sofisticação do gospel criaram reações, em especial das igrejas mais conservadoras e tradicionalistas.

Contudo, ainda no século XX, nos anos 50 , surge, na Alemanha, a chamada Música eletrônica (BENNET, 2007). Microfones (já existiam e são ainda mais utilizados) e geradores eletrônicos de som passam a ser usados no fazer musical, o que transforma por demais a música praticada daí em diante. É a partir de então que novos instrumentos vão surgindo, bem como novas maneiras de tocar, cantar e compor. Surgem a guitarra elétrica, os órgãos eletrônicos, os sintetizadores e teclados de hoje, dentre vários outros recursos que possibilitaram diversas alterações nos sons.

Nos anos 60 , os pentecostais romperam com a tradição da hinologia protestante, Introduziram ritmos e estilos populares nas canções, incluíram instrumentos de percussão e sopro no acompanhamento e compuseram pequenas canções com melodias e letra simples para serem cantadas nos cultos - algo muito próximo do que seria mais tarde popularizado entre os evangélicos como os "corinhos".

Entretanto, no meio eclesiástico, estas mudanças sofreram, a princípio, certa resistência. No Brasil, por exemplo, muitas igrejas rejeitaram o uso de instrumentos como a bateria e a guitarra elétrica, afirmando serem estes "instrumentos do diabo". Isso porque os tais instrumentos eram largamente utilizados na música secular, o que gerou tal rejeição.

Ficou claro, que tais pessoas, não atentavam para o fato de ter sido o piano, até poucas décadas antes, um instrumento usado em botecos, cabarés, dentre outros lugares que jamais seriam admirados pelos líderes de igreja. $\mathrm{O}$ piano se tornara extremamente popular, nos primeiros sambas e choros, e deixara de ser um instrumento apenas "erudito" e muito menos seria um instrumento "sacro", sagrado.

Nos Estados Unidos, a origem do grupo denominado "Equipe de louvor adoração" remonta à fundação da Capela do Calvário em 1965. Chuck Smith, o fundador da denominação, começou um ministério para "hippies e surfistas". Smith convidou 
hippies convertidos a tomar suas guitarras e tocar sua música agora redimida na igreja. A nova forma musical começou a ser chamada "louvor e adoração". Enquanto o Movimento de Jesus crescia, Smith fundou a MaranathaMusic em 1973. A meta era divulgar a música destes jovens artistas (CCM, 2007).

Sob a influência do músico John Wimber foi criado uma capela denominada "A Vinha" em 1977. Este novo modelo de igreja mais contemporâneo seguiu com o conceito de equipe de louvor. Outra igreja que influenciava o novo modelo de adoração foi a Anaheim Vineyard Christian Fellowship, Capela do Calvário. Os dois modelos de cultos exerceram grande influência sobre a família cristã com suas equipes de louvor e de adoração. A música da Vinha era considerada mais intimista e tranqüila, enquanto que a da Capela era mais conhecida por seus cânticos agitados e dançantes.

Influenciados pelo movimento musical jovem presente nas igrejas estadunidenses é que nos anos 70, no Brasil, surgem grupos como o Rebanhão, Vencedores por Cristo, Ellus e Logos (grupos jovens da Igreja Batista). Pioneiros no uso de vários instrumentos musicais usados por jovens do movimento Rock, Hippie e influenciados pelos Beatles.

Os grupos musicais buscavam uma nova qualificação técnica dos músicos das congregações espalhadas Brasil afora. Estes jovens que lideraram o movimento e outros que também foram se apropriando da nova liturgia musical enfrentaram uma grande oposição por quererem utilizar guitarra elétrica, bateria e baixo elétrico e praticar a música de seu tempo, a música de sua época, dentro das igrejas.

Apesar da grande oposição vinda das igrejas cristãs mais tradicionais, assim o fizeram, sendo os grandes responsáveis pelo tipo de música que hoje praticam as igrejas em sua maioria. Eles foram os músicos de vanguarda na quebra de velhos paradigmas, dando-nos a possibilidade de, assim como eles, fazer a música de nosso tempo, não estando presos a tradicionalismos infundados e historicamente equivocados. Eles serviram à seu tempo e geração, deixando grandes lições para todos nós. 
É bem verdade que algumas denominações ainda resistem ao uso de tais instrumentos e a esse estilo de música "mundana" (assim denominada por essas igrejas mais tradicionais), mas o quadro está bastante mudado, não é mesmo?

Nos anos 80 , os produtores da chamada música 'gospel' (termo este originalmente criado para se referir a um tipo específico de música cristã norte-americana, mas que tem sido utilizado para se referir à música cristã atual), começaram a investir em cantores e músicos, a princípio, evangélicos e, posteriormente, também católicos, contribuindo significativamente para o crescimento da indústria fonográfica do gênero.

Com o surgimento do neo-pentecostalismo, já nos anos 90 , vão surgindo os primeiros sucessos internacionais na música gospel, brasileira que são: O rock cristão vai ganhando espaço através de várias bandas musicais tais como: Oficina G3, Catedral, Fruto Sagrado e outros estilos vão também sendo apresentados ao público: o samba e o pagode, o forró, o hip hop e tantos outros, a princípio rejeitados, passam a ser parte integrante da chamada música gospel, o que mais uma vez influencia por demais a música praticada dentro das igrejas, já que seus membros, por admirarem estes artistas de renome, são por eles influenciados e tencionam praticar a música que eles praticam em suas próprias comunidades (OMENA, 2011).

\section{A CRIAÇÃO DE ESCOLAS DE MÚSICA NAS IGREJAS EVANGÉLICAS}

A religião é um dos ambientes que proporciona e viabiliza a educação. Inserida neste meio está à prática de ensino musical. A música não é ensinada apenas nas escolas mais também, em centros comunitários, associações, clubes, hospitais, abrigos, empresas, instituições não escolares e nas igrejas, que será o local abordado neste trabalho.

A educação formal é aquela que se refere à estruturação, organização e o planejamento intencional de um modo sistemático. Assim pode-se dizer que aonde há ensino (escolar ou não) ali está presente a educação formal (Libâneo, 2007). 
Podemos considerar que aulas em salas específicas, das igrejas evangélicas são aulas estruturadas, mas de forma informal. "(...) o termo informal é o mais adequado para indicar a modalidade de educação que resulta do "clima" em que os indivíduos vivem, envolvendo tudo o ambiente e as relações socioculturais e políticas que se fundem no indivíduo e no grupo (Libâneo, 2007). Também "A aprendizagem musical informal na Igreja acontece pelo uso comum e pela compreensão comum que se amplia pelo uso" (Kerr, p.5, 2004).

As diferentes formas educacionais foram desenvolvidas objetivando tornar o ensino mais prazeroso e proporcionar o aumento do interesse dos estudantes. São elas: educação formal, não-formal e informal. Os elementos que diferenciam esta classificação são os relativos à organização e à estrutura do processo de aprendizagem.

Várias igrejas evangélicas se propõem a forma sua comunidade eclesiástica e sua comunidade social (pessoas pertencentes ao bairro no qual a igreja está instalada). Pode-se perceber pela presença de estudantes de música presentes nas escolas formais de música como exemplo: citamos a Faculdade de Música do Espírito Santo.

Este movimento de renovação presente em vários líderes teólogos e músicos desde a idade média influenciaram a formação musical, presente na igreja cristã protestante que a princípio, desligada da igreja cristã católica, começou a criar seus próprios recursos de existência e persistência na história da igreja.

Percebe que a presença de músicos evangélicos tem mudado o cenário das igrejas que recebem de volta seus fiéis com uma formação mais ampla do que seja o conceito de música. Assim, vimos por meio desta pesquisa analisar a influência musical de igrejas evangélicas na formação de músicos que estudam na escola formal de música, ou seja, nos cursos de Bacharelado da Faculdade de Música do Espírito Santo FAMES. 


\section{METODOLOGIA}

A abordagem metodológica adotada nessa pesquisa é de natureza qualitativa, pois a mesma dá ênfase a interpretação e compreensão do fenômeno, buscando fazer uma leitura descritiva do objeto. Segundo Ludke (1986), a pesquisa qualitativa tem o ambiente natural como sua fonte direta de dados e o pesquisador com seu principal instrumento; os dados são predominantemente descritivos; a preocupação com o processo é muito maior do que com o produto; o significado que as pessoas dão às coisas e à sua vida são focos de atenção especial pelo pesquisador; e a análise dos dados tende a seguir um processo indutivo. Estas são as características gerais. Assim, a pesquisa qualitativa pode assumir diversas formas, dentre as quais, a do tipo etnográfico e o estudo de caso.

A pesquisa foi feita com 5 alunos evangélicos formados: um é formando no curso de Bacharelado da Fames os outros quatro formados na UFES. Foram esses escolhidos por existir na igreja evangélica um incentivo na área de metais ou sopros, sendo essa prática mais comum nesse meio e também por serem evangélicos com formação inicial parecida.

Tendo em vista os objetivos desta pesquisa, o instrumento para coleta de dados foram os questionários abertos e fechados de natureza impessoal e também entrevistas com o grupo de amostragem.

De acordo com Yin (1990) podem ser utilizadas quatro diferentes fontes de informações internas em um estudo de caso: documentos, estatísticas, entrevistas pessoais e observação direta.

Os questionários foram entregues pessoalmente com uma semana de antecedência para cada participante, para garantir o sigilo dos dados e o anonimato dos mesmos. Laville; Dionne (1999) afirma que uma das vantagens do questionário é que "facilita a compilação e a comparação das respostas escolhidas e permite recorrer ao aparelho estatístico quando chega o momento da análise". 
Recorre-se à entrevista sempre que se tem necessidade de obterem dados que não podem ser encontrados em registro e fontes documentais e não podem ser fornecidas por qualquer informante [..], recorre-se à entrevista quando não há fontes seguras às informações desejadas (CERVO, 2002, p.46 e 47).

Este trabalho analisou os dados obtidos através de questionários abertos e fechados pela metodologia de Pesquisa Qualitativa onde pudemos compreender a formação do músico, saber da sua atuação e trajetória musical. Todos os entrevistados iniciaram seus estudos musicais na igreja e também estimulados por ela.

Analisaremos o questionário contendo 11 perguntas que foi aplicado em uma única parte. Os resultados obtidos pela pesquisa qualitativa orientaram melhor a compreensão dados das entrevistas.

\section{RESULTADOS E DISCUSSÃO DOS DADOS}

Foram entrevistados cinco músicos distintos, sendo que a área de atuação específica de cada um é diferente. Quanto à qualificação todos eles obtiveram o curso de bacharelado em música.

Portanto, à habilitação temos três áreas distintas 3 trombones, 1 trompete e 1 violino. Em cursos de bacharelado em música é habitual o uso de habilidades específicas, por isso mesmo fizemos questão de envolver pessoas de diversas áreas, ligadas a diferentes campos de performance.

Para Freitas (2008), as igrejas estão cobrindo o papel antes reservado aos cursos básicos e técnicos de música. Mesmo sendo instituições que não são formadas para a formação musical, encontramos um aumento relevante do número de alunos que vêm das igrejas ingressando nas Universidades.

É um ponto comum entre os músicos entrevistados, todos começaram a estudar música ou ter contato com algum instrumento no próprio ambiente familiar. Curiosamente, outro ponto comum entre eles foi à influência direta da religião no 
estudo da música, sabemos que existe grande incentivo das comunidades religiosas para o aperfeiçoamento da música entre os seus fiéis.

"Mesmo assim as igrejas tornam-se ambiente de exposição e prática musical, com uma regularidade que não se costuma se perceber em outros contextos (...)" (Costa, p.15, 2008). "O aluno que está estudando música é um veículo propagador de crescimento, pois ensina o pouco que sabe, inclusive na igreja” (Bastos, p.18, 2004).

Para tanto, é necessário uma média geral para compreendamos as idades dos meus entrevistados. O mais novo deles começou estudar com cinco anos por influência paterna. Os outros quatro entrevistados começaram com: 7, 10, 13 e 15 anos. Apenas um dos músicos começou estudar um pouco mais tarde que média geral, pois foi aos 15 anos. Não é tão comum começar estudar música tão tarde, visto que há uma ênfase muito grande nas igrejas evangélicas para que seus participantes iniciem seus estudos musicais o mais cedo possível. Mas isto não significa que o mesmo não tenha as mesmas habilidades para tocar que os outros quatro, pois o fato de participar de grupos musicais ou corais nas igrejas evangélicas, já é uma iniciação musical.

As igrejas protestantes, em função da valorização da música em seus cultos, enfatizam a educação musical, ainda que Informalmente. Muitas igrejas evangélicas possuem uma escola de música, que atende não somente aos seus congregados em várias faixas etárias, mas também a pessoas da comunidade. (MARTINOFF, 2010, p.68)

Como foi relatado anteriormente, reitero a normalidade do incentivo ao estudo da música dentro das comunidades religiosas. Surge de uma forma curiosa o fato de que todos os entrevistados participam de comunidades onde a música é matéria de ensino. As escolas de música estão presentes em algumas instituições religiosas, foi o fato apresentado pelos entrevistados.

Segundo Bastos (2004) a presença de evangélicos é muito forte nas escolas de música de todo o Brasil. Vieira (2004) afirma através de uma pesquisa que $100 \%$ dos 
músicos da Banda Sinfônica do Corpo de Fuzileiros Navais tiveram a sua iniciação musical em alguma Igreja Evangélica.

Para quem estuda música, em geral, a formação é muito influenciada pelo local onde se pratica. Além disso, a experiência com a música não se da através do intelecto apenas, pelo contrário, é preciso oportunidades de executar na prática o que se estuda. Exatamente por essa razão, percebe-se em todos os cinco entrevistados ao confirmarem e assumirem a importância da comunidade religiosa nas suas formações musicais.

Segundo pesquisa de Favaro (2007), "as igrejas que mais formam músicos são a Assembléia de Deus, a Igreja Batista e a Congregação Cristã no Brasil”. Nas duas primeiras, os fiéis aprendem a tocar desde hinos evangélicos orquestrados até peças consagradas da música sacra, como as compostas por Johann Sebastian Bach.

Antes de pensarmos sobre a separação dos termos secular e cristã, precisamos esclarecer que a música em si mesma não tem nada haver com isso, ou seja, é uma expressão artística e não necessariamente religiosa. Mas o uso da música pode ser direcionado para vários objetivos diferentes. Esse é um tema discutido ao longo da história da igreja por Calvani que geralmente traz separações e divisões pelas opiniões distintas. Há quem entenda música como arte, Castro, (2010). Há quem entenda música como entretenimento religioso, Cunha, (2007).

Há também quem acredita e se expressa como se a música pudesse ser dividida entre a sacra e diabólica como Bacchiocchi (2012). Este é o caso da concepção de algumas igrejas e lideranças neo - pentecostais.

Os músicos responderam que a música não é sacra ou profana, mas a diferença está na funcionalidade da mesma. Segundo Merriam (1964), a música é funcional e pode estar dividida em várias categorias.

Foi interessante observar as respostas dos músicos, pois os mesmos demonstraram ter uma definição e uma percepção clara e fundamentada da definição e do conceito de música. Uma delas foi assim: o primeiro entrevistado disse que boas ou ruins, 
seguem os mesmos padrões e afinidades. O que diferencia fora o lado musical que é o ritmo, harmonia, estilo, arranjo, interpretação e concepção é o propósito em que ela foi escrita. Já a segunda pessoa entrevistada disse que a música é uma arte que traz qualquer tipo de sensação (tensão, relaxamento, suspense, medo, êxtase, alegria, tristeza, etc) à alma do ser humano. O som do piano, do trombone, bateria ou qualquer instrumento, é o mesmo, porém a intenção da execução direciona para quem e o porquê daquilo. Diferentemente da igreja, onde tudo é voltado para adoração, respeitando uma série de costumes e princípios religiosos.

Para o profissional de música, ou seja, aquele que vive e sobrevive da música, cada área tem uma realidade, inclusive financeira. Entre os entrevistados, há todo tipo de atuação, o primeiro deles atua na área popular, o segundo trabalha em todas áreas caminhando mais para o estilo "Jazz Brasil", o terceiro e quarto militar, o quinto erudito e gospel. Ou seja, os músicos reafirmam a resposta anterior onde o sacro e o profano não são espaços de controvérsias, mas sim de diálogo e de funções diferentes.

Segundo o professor Gloeden (2012), que dá aulas de violão erudito na Emesp (São Paulo), a carreira de músico "é mais uma vocação do que uma profissão" (...).

Ao tocar nessa questão, precisamos compreender antes de tudo qual o tipo de comunidade religiosa iremos comentar. Se falarmos de catolicismo, a realidade é completamente diferente do protestantismo, pois neste último há uma tradição em ter umas pessoas que organize a música e que seja remunerado.

Sendo assim, falaremos dentro da gama protestante, teremos literalmente centenas de exemplos para dar, logo essa pergunta não pode ser um questionamento fechado. Curiosamente, todos os entrevistados concordam com a remuneração vinda da comunidade.

Por muito tempo algumas comunidades tinham e ainda têm que as pessoas que se dedicam as atividades eclesiásticas deveriam atuar somente por vocação. Mas esta mentalidade tem avançado em alguns espaços e hoje há vários músicos que atuam 
nas comunidades religiosas e são remunerados. Percebe-se que as instituições estão valorizando e vendo estes músicos como profissionais.

Martinoff (2010), afirma que as igrejas protestantes, em função da valorização da música em seus cultos, enfatizam a educação musical, ainda que informalmente.

Muitas igrejas evangélicas possuem uma escola de música, que atende não somente aos seus congregados em várias faixas etárias, mas também pessoas da comunidade. Nesta área do contexto ministerial é mais do que necessário investir, pois também é cuidar da saúde espiritual da igreja de Cristo daqueles que se dedicam para isso.

O que se observa no mercado chamado gospel é um farto seleiro de estudantes de música que tem levado em frente à vocação como profissão. O primeiro entrevistado disse que o mercado de trabalho não te rotula a não ser que você queira trabalhar apenas com um ou outro seguimento específico.

Também foi percebido nas respostas dos outros entrevistados que o que importa na pratica não é apenas onde se deu a formação, mas também a experiência dos músicos para trabalhar em determinado mercado musical. Interessantemente o segundo entrevistado disse que não concorda, pois o mercado quer músicos que sejam rápidos e práticos, e geralmente, os músicos de igrejas possuem uma percepção musical bem aguçada, pois começaram bem cedo.

Segundo Marcos Sotter (2012), a carreira profissional em qualquer área exige sempre muita dedicação. A música, porém, requer, além de talento, também persistência. $O$ sucesso, assim como o retorno financeiro, depende da coragem e determinação de seguir adiante. Quem escolheu a música como profissão garante: é possível sim, viver de música, seja no palco ou lecionando.

A música é uma forma de arte que se constitui basicamente em combinar sons e silêncio seguindo uma pré-organização ao longo do tempo. "Embora nenhum critério científico permita estabelecer seu desenvolvimento de forma precisa, a história da 
música confunde-se, com a própria história do desenvolvimento da inteligência e da cultura humana."

Olivier Messiaen (1908-1992), não entendia nenhuma separação entre a linguagem estético-musical na liturgia e fora dela, dando como exemplo o próprio Mozart: (...) que utilizou exatamente a mesma linguagem para obras de tendências marcadamente profana e para obras de caráter profundamente religioso sendo bem sucedido nos dois casos e isso sem modificar os seus cânones estéticos (...) MESSIAEN (1986).

No caso desta pesquisa, todos tiveram formação religiosa. Se a pessoa tem uma leitura técnica suficiente para ler qualquer tipo de coisa, a música é independente se o repertório é religioso ou não. Eles afirmaram que para sua visão pessoal não há diferença, apesar de sofrer preconceito por parte de algumas pessoas evangélicas.

Também há um exemplo extremo que obtivemos em uma das respostas na pesquisa: "Músicos evangélicos são apenas músicos separados para tocar louvor e hino", disse o entrevistado de número 5 como se houvesse diferença entre as notas musicais dos hinos para as notas usadas no repertório popular. Esta resposta mostra não apenas deste músico, mas de uma comunidade que determina muito a música que pode ou não.

Quando se fala de mercado o assunto é particular de cada localidade, repertório e realidade musical. Existem experiências de quem acredita na sorte e de fato as coisas acontecem. Existem outras experiências de quem acredita na preparação continua do músico para então, estar habilitado para quando a oportunidade aparecer. O que é inquestionável entre os entrevistados é a importância da capacitação profissional.

Ao analisar as respostas dos entrevistados pode-se concluir que para engrenar no mercado da música é necessário o aprimoramento técnico e oportunidade. Interessantemente, um dos entrevistados citou: buscar a capacitação profissional com seriedade e nunca se dar por satisfeito procurando sempre se atualizar, pois a música é um universo infinito. 
Para Caxito (2010), umas séries de competências estão interligadas a este assunto. Ter a correta e clara visão de seus objetivos de longo prazo, se planejar para alcançar estes objetivos, desenvolver um bom network, criar e investir em sua marca pessoal. Também é muito importante aprender a falar em público, a construir equipes de trabalho e a compartilhar esforços e resultados.

Em suma o profissional, precisa se apoiar em um tripé formado pela motivação, pela disciplina (para manter sempre seus objetivos em foco) e pela flexibilidade (para se adaptar as mudanças e continuar perseguindo seus objetivos).

\section{CONCLUSÃO}

Através dos estudos realizados, pode-se concluir que os objetivos formulados para solucionar o problema proposto que norteava, a música como agente transformador na vida dos indivíduos foram alcançados com sucesso.

Nesta pesquisa, buscamos aprofundar nossos conhecimentos concernentes a música, para isso, foi realizada uma entrevista, com alunos de bacharel formados pela Faculdade de Música do Espírito Santo, com o intuito de saber, quais seriam as dificuldades e facilidades dentro do mercado de trabalho. Também, descobrir o que pensam em relação à música secular e cristã podendo construir um caminho democrático neste projeto.

Historicamente, o ensino de música nas igrejas evangélicas tem contribuído e propiciado a formação de músicos que atuam em orquestras, corais e bandas em todo o país, fora do âmbito das próprias igrejas. Muitos músicos que atuam no circuito da música popular urbana, também tiveram sua formação inicial nas igrejas evangélicas. Uma parcela dos alunos que frequentam conservatórios, cursos técnicos, de bacharelado e licenciatura em música, também teve sua iniciação musical em igrejas evangélicas. 
Por conseguinte, a música evangélica possui peculiaridades, é um gênero musical produzido e composto para expressar a crença individual de pessoas ou de uma comunidade cristã.

A criação, a performance, a influência e a definição variam de acordo com a cultura e o contexto social. Sendo a música na igreja evangélica mediadora de significados, tem aspectos estéticos e sua função básica é de possibilitar a manifestação ao sagrado e do culto religioso como expressão de adoração a um deus no qual a comunidade o tem como o supremo da criação.

Identificamos na pesquisa que a música tem sido uma parte importante do culto na maioria das igrejas evangélicas, por isso inúmeros músicos são formados nesse contexto. Justamente por esse processo de formação, oportuniza as pessoas o desenvolvendo de habilidade musical e até mesmo a possibilidade de aprender um instrumento ou cantar. Esse fenômeno criou, involuntariamente, nas igrejas evangélicas brasileiras um mercado de formação musical.

O questionário aplicado aos entrevistados trouxe-nos questionamentos e reflexões, na medida em que foi permitido compreender sua formação inicial musical até a sua vida de músico profissional.

Ao analisarmos, vimos que há uma grande abertura no mercado musical para esses músicos profissionais denominados cristãos evangélicos que naturalmente vem crescendo e contribuindo ao abastecer as bandas de formal geral com músicos profissionais e competentes.

A formação religiosa e também musical é considerada diferencial por alguns profissionais que trabalham recrutando músicos para gravação, shows e turnês, segundo as respostas apresentadas.

$\mathrm{Na}$ realidade pós-moderna, ninguém vive isento das influências de outras culturas. Até mesmo, aqueles que têm estilo de vida baseado em uma filosofia, que conteste alguns padrões vigentes, como é o caso dos cristãos evangélicos, é importante enfatizar e perceber que as pessoas não podem viver isoladamente, em contextos apenas 
eclesiásticos, principalmente se tratando da música que tem várias funções sociais (MERRIAM, 1964).

Espera-se que esta pesquisa venha ajudar a esclarecer questões relacionadas ao entendimento da música secular e cristã bem como vida profissional musical sejam elas pessoas evangélicas ou não. Uma vez que precisamos ter uma prática musical profissional eficaz e eficiente independentemente do contexto que somos inseridos para atuarmos como músicos.

\section{REFERÊNCIAS BIBLIOGRÁFICAS}

BACCHIOCCHI, Samuele. O Cristão e Música Rock. Julho, 2012. Disponível em: http://musicaeadoracao.com.br/28272/o-cristao-e-a-musica-rock-capitulo-3/

BASTOS, Gisele. Tom do céu - estudantes evangélicos são a maioria em muitas escolas brasileiras de música. Revista Graça, p. 16-19, Rio de Janeiro, Edição ํํ55, fev/2004.

BENNET, Roy. Uma breve história da música. Rio de Janeiro: Jorge Zahar Ed., 2007.

BRITO, Teca Alencar de. Música na educação infantil: proposta para a formação integral da criança. 2.ed. São Paulo: Petrópolis, 2003.

CAIRNS, EarleE. O cristianismo através dos séculos: uma história da Igreja Cristã. São Paulo: Vida Nova, 1995.

CASTRO, Ramalho. O pensamento criativo de Paul Klee: arte e música na constituição da Teoria da Forma, Belo Horizonte, 2010, p.7-18. Disponível em: https://www.ufmg.br/online/arquivos/anexos/num21_cap_01.pdf.pdf

CAXITO, Fabiano. Não deixo a vida me levar, a vida levo eu! Editora Saraiva, São Paulo. Agosto 2010. Disponível em: http://www.catho.com.br/carreirasucesso/entrevistas/fabiano-caxito-como-alavancar-sua-carreira 
CERVO, Amado Luiz \& BERVIAN, Pedro A. Metodologia científica. 5.ed. São Paulo: Prentice Hall, 2002.p.46 e 47.

Cicero Barros, A música gospel tem uma longa história de evangelização, disponível em: http://www.analiseagora.com/2014/03/a-musica-gospel-tem-umalonga-historia.html, 13 de Março de 2014.

COSTA, Henrique Gonçalves. Características do aprendizado musical e função dos ministérios de louvor das igrejas evangélicas brasileiras. Monografia. p. 2-16 Rio de Janeiro, UFRJ, 2008.

CUNHA, Magali do Nascimento. A Explosão Gospel. Um olhar das ciências humanas sobre o cenário evangélico contemporâneo. Rio de Janeiro: Mauad, 2007.

Enciclopédia Mirador Internacional, "Da Página 3 Pedagogia \& Comunicação", disponível em: “ http://educacao.uol.com.br/biografias/lutero.jhtm.”

FAVARO, Thomaz. Os Evangélicos dão o tom. Revista Veja. Rio de Janeiro. Edição no427, junho 2007. Disponível em veja.abril.com.br/060607/p_104.shtml.

FREITAS, Débora. Educação Musical Formal, Não-formal e Informal: Um estudo sobre processos de ensino da música nas Igrejas Evangélicas do Rio de Janeiro. Rio de Janeiro: UNIRIO, 2008. Monografia de conclusão de curso de graduação em Música.

FREITAS, Marcos. Breve História da Música na Igreja. Rio Grande do Norte, 2013. GAINZA, Wilhems. Estudos de psicopedagogia musical. [tradução de Beatris A. Cannabrava]. 2.ed. São Paulo: Summus,1988.vol.31.

GLOEDEN, Everton. Guia de carreiras: música. 2012. Disponível em: http://g1.globo.com/educacao/guia-de-carreiras/noticia/2012/04/guia-de-carreirasmusica.html 
GROUT, Donald J.; PALISCA, Claude V. História da Música Ocidental. Lisboa: Gradiva, 1994.

Jonatha Cardoso, Série sobre a história dos grandes hinos da música cristã, disponível em: http://www.supergospel.com.br/noticia_serie-sobre-a-historia-dosgrandes-hinos-da-musica-crista-parte-4-a-mensagem-da-cruz_2905.html, R.J, 2011.

KERR, Samuel ; Dorotéia. Música e Educação no protestantismo brasileiro. Tempo e Memória. Revista do Programa Interdisciplinar em Educação, Administração e Comunicação. Universidade São Marcos, ano 2, n², p. 113-120, janeiro-julho 2004.

KRZESONKI, Mazilda T. da Silva; CAMPOS, Silmara Streit de. A importância da linguagem musical para a aprendizagem da criança. Revista de divulgação técnico-científico do ICPG. v. 2, n.8, p.115-119, jan./jun.2006.

LIBÂNEO, José Carlos. Pedagogos e pedagogia, para que? Editora Cortez, p. 8695, São Paulo, 2007.

LUDKE, Menga \& ANDRÉ, Marli E.D.A. Pesquisa em educação: abordagens qualitativas. São Paulo, Editora, Pedagógica e Universitária, 1986. 99p.

Luiz Carlos Ramos, Mais do mesmo: a cultura gospel e o moderno tradicional, disponível em: https://www.metodista.br/revistas/revistasims/index.php/CA/article/viewFile/1242/1257, R.J, 2007.

MARCOSSOTTER, $2012 . \quad$ "Profissão: Músico". Disponível em: http://www.agoranapolis.com.br/?acao=detalhar_noticia\&ref=154

MARTINOFF, Eliane Hilário da Silva. A música evangélica na atualidade: algumas reflexões sobre a relação entre religião, mídia e sociedade. Revista da ABEM, Porto Alegre, V. 23, 67-74, mar. 2010.

MARTINS, Dan. Igrejas evangélicas viraram fornecedoras de músicos profissionais para bandas e artistas seculares, disponível em: 
Noticias.gospelmais.com.br/igrejas-evangélicas-fornecedoras-musicos-bandasseculares-31288-html, 04 de Março de 2012.

MERRIAM, Alan P. The Anthropology of Music de 1964. Disponível em: http://hugoribeiro.com.br/biblioteca-digital/Merriam-the_Anthropology_Music.pdf

MESSIAEN, Olivier. Musique et couleur. Paris 1986, p 21-22.

OLIVEIRA, Yvelise. Entrevista - A música cristã muda o compasso. Vinde - Revista evangélica, Rio de Janeiro, ano IV, n.40, p.20-28, 1999.

ROSA, N. S. S. Educação musical para pré - escolar. São Paulo: Ática, 1990.

VERAS; MEDEIROS; MATTOS. A CONTRIBUIÇÃO DO ENSINO DA MÚSICA SACRA PARA A EDUCAÇÃO MUSICAL NO CARIRI. Ceará, outubro de 2011.

VIEIRA, Themístocles. A alfabetização musical da Banda Sinfônica do Corpo de Fuzileiros Navais. Monografia, 2004.

Will Durant, The Age of Faith (New York: Simon \& Schuster, 1950), p. 1027.

YIN, Robert K. Case study research: desing and methods. EUA: Sage Publications, 1990.

Recebido: Janeiro, 2018.

Aprovado: Dezembro, 2018. 